\title{
APLIKASI PENYEWAAN BUS BERBASIS WEB PADA PO. NUANSA ILHAM SUKABUMI
}

\author{
Renny Oktapiani ${ }^{1}$, Dicki Prayudi $^{2}$, Resti Yulistria ${ }^{3}$, Nur Islamiyati ${ }^{4}$, Siti Nazmah $^{5}$ \\ 1,2,3,4,5 Universitas Bina Sarana Informatika (UBSI) \\ renny.rop@bsi.ac.id, dicki.dcd@bsi.ac.id, resti.res@bsi.ac.id, nurislamiyati90@gmail.com, \\ s.nazmah@gmail.com
}

\begin{abstract}
ABSTRAK
PO.Nuansa Ilham adalah perusahaan yang bergerak di bidang jasa transportasi yang menyediakan armada bus pariwisata, sementara dalam pengelolaan data penyewaan PO.Nuansa Ilham umumnya masih manual. Hal tersebut dapat menimbulkan masalah dalam proses pencatatan data penyewaan dan dalam pembuatan laporan penyewaan bus karena banyak data yang tercecer. dengan Perancangan sistem informasi penyewaan bus ini akan memudahkan administrasi dalam mengelola transaksi penyewaan bus dan juga dalam pembuatan laporannya. Pengembangan sistem informasi dalam pembuatan aplikasi ini menggunakan metode Waterfall, dan bahasa pemrograman yang dipakai adalah JAVA, serta database MySQL. Hasil dari penelitian ini adalah memudahkan administrasi dalam menggunakan sistem yang terkomputerisasi untuk meminimalisir tingkat kesalahan dan memudahkan dalam pengolahan data, penyimpanan maupun pengolahan laporan. Dengan bantuan sistem terkomputerisasi, maka pembuatan laporan lebih cepat di proses, tepat efektif juga efisien dan dapat memudahkan dalam pencarian data yang dibutuhkan. Juga meminimalisir resiko kesalahan yang diakibatkan oleh human error.
\end{abstract}

Kata Kunci : JAVA, MySQL, Rancang Bangun Sistem Informasi, Waterfall.

\begin{abstract}
PO. Nuansa llham is a company engaged in the field of transportation services that provides a tourist bus fleet, while in managing data rental PO. Nuansa Ilham is generally still manual. This can cause problems in the process of recording rental data and in making bus rental reports because a lot of data is scattered. The design of the bus rental information system will facilitate the administration in managing bus rental transactions and also in making reports. The development of information systems in making this application uses the Waterfall method, and the programming language used is JAVA, and the MySQL database. The results of this study are to facilitate administration in using a computerized system to minimize error rates and facilitate data processing, storage and report processing. With the help of a computerized system, making reports faster in the process, effective right is also efficient and can facilitate the search for needed data. Also minimizes the risk of errors caused by human errors.
\end{abstract}

Keywords: JAVA, MySQL, Information System Design, Waterfall.

\section{Pendahuluan}

Seiring berkembangnya teknologi informasi yang semakin cepat dan canggih, telah memberikan banyak manfaat pada kehidupan manusia. Manfaat pengguna teknologi informasi tersebut diantaranya dalam pengelolaan data informasi pada kalangan masyarakat tertentu guna menunjang dan meningkatkan usaha yang dikelolanya. (Prasetyo, 2014).

Romney dan Steinbart dalam (Kandouw, 2013) menyatakan bahwa "Sistem Informasi Akuntansi (SIA) adalah sumber daya manusia dan modal dalam organisasi yang bertanggung jawab untuk (1) persiapan informasi keuangan dan (2) informasi yang diperoleh dari 
mengumpulkan dan memproses berbagai transaksi perusahaan".

Perancangan sistem aplikasi penyewaan berbasis komputer ini bisa membantu pendataan pengelolaan barang, mempercepat transaksi penyewaan serta pegawai bisa memberikan laporan hasil dari penyewaan kepada pemilik dan mampu mempermudah pekerjaan secara komputerisasi yang lebih efesien dan efektif (As \& Fitriani, 2016).

Dalam penyewaan bus, dengan tidak adanya sistem basis data penyewaan bus untuk menyimpan data-data hasil penyewaan dan penjadwalan, sehingga sulitnya mencari data. Aplikasi penyewaan dibuat untuk mempermudah costumer dalam melakukan penyewaan bus agar semua data-data yang diperoleh dapat tersusun rapi dalam database. (fitria \& nisa, 2017). Dengan demikian data pencatatan yang dimiliki akan selalu update dengan transaksi yang dilakukan setiap saat. Sistem pencatatan yang terkomputerisasi juga mendukung pemilik dalam rangka pengambilan keputusan.

PO. Nuansa llham adalah perusahaan yang bergerak di bidang jasa transportasi yang menyediakan armada bus pariwisata. Transportasi adalah alat yang sangat penting untuk membantu kita dalam kehidupan sehari-hari, baik itu secara pribadi ataupun angkutan umum. Karena keterbatasan kemampuan dalam membeli sebuah alat transportasi maka banyak masyarakat yang lebih memilih menyewa kendaraan. Oleh karena itu adanya penyewaan bus sangatlah membantu masyarakat dalam bertransportasi, Dalam prosedur penyewaan bus pariwisata, costumer dapat langsung mendatangi kantor PO. Nuansa Ilham, sementara dalam pengelolaan data penyewaan, PO. Nuansa Ilham umumnya masih manual. Hal tersebut dapat menimbulkan masalah dalam proses transaksi dan pencatatan laporan penyewaan bus karena banyak data yang tercecer.

a. Metode pengumpulan data

Untuk memperoleh data yang akurasi dan relevan penulis melakukan teknik pengumpulan data yaitu:

1) Observasi

Dalam hal ini penulis melakukan observasi atau pengamatan langsung pada PO Nuansa Ilham.
2) Wawancara

Adalah komunikasi dua arah untuk mendapatkan data dari responden yang dapat dipercaya sebagai masukan untuk melengkapi penelitian ini.

3) Studi Pustaka

Studi Pustaka yang dilakukan,yaitu dengan mempelajari serta

mengumpulkan teori-teori yang relevan dengan topik yang dibahas guna memperoleh data serta informasi tertulis yang berhubungan dengan masalah yang dikemukakan.

\section{Metode Pengembangan Sistem}

Proses Pengembangan Perangkat Lunak (Sofware Development Process) adalah suatu penerapan struktur pada pengembangan suatu Perangkat Lunak (Software), yang bertujuan untuk mengembangkan sistem dan memberikan panduan untuk menyukseskan proyek pengembangan sistem melalui tahapantahapan tertentu.

Model pengembangan sistem yang digunakan adalah Model Sekuensial Linier (Waterfall Development Model) dengan menggunakan sebuah pendekatan perkembangan perangkat lunak yang berurutan serta sekuensial, dimulai dari tingkat dan kemajuan sistem pada seluruh tahapan analisis, desain, kode, pengujian dan pemeliharaan. Tahapan-tahapan untuk Pengembangan Model Sekuensial Linear (Waterfall Development Model):

\section{a. Requirement Analisis}

Tahap ini pengembang sistem diperlukan komunikasi yang bertujuan untuk memahami perangkat lunak yang diharapkan oleh pengguna dan batasan perangkat lunak tersebut. Informasi ini biasanya dapat diperoleh melalui wawancara, diskusi atau survei langsung. Informasi dianalisis untuk mendapatkan data yang dibutuhkan oleh pengguna.

\section{b. System Design}

Spesifikasi kebutuhan dari tahap sebelumnya akan dipelajari dalam fase ini dan desain sistem disiapkan. Desain Sistem membantu dalam menentukan perangkat keras(hardware) dan sistem persyaratan dan juga membantu dalam mendefinisikan arsitektur sistem secara keseluruhan.

c. Implementation 
Pada tahap ini, sistem pertama kali dikembangkan di program kecil yang disebut unit, yang terintegrasi dalam tahap selanjutnya. Setiap unit dikembangkan dan diuji untuk fungsionalitas yang disebut sebagai unit testing.

\section{d. Integration \& Testing}

Seluruh unit yang dikembangkan dalam tahap implementasi diintegrasikan ke dalam sistem setelah pengujian yang dilakukan masing-masing unit. Setelah integrasi seluruh sistem diuji untuk mengecek setiap kegagalan maupun kesalahan.

\section{e. Operation \& Maintenance}

Tahap akhir dalam model waterfall. Perangkat lunak yang sudah jadi, dijalankan serta dilakukan pemeliharaan. Pemeliharaan termasuk dalam memperbaiki kesalahan yang tidak ditemukan pada langkah sebelumnya. Perbaikan implementasi unit sistem dan peningkatan jasa sistem sebagai kebutuhan baru.

\section{Hasil dan Pembahasan}

Analisa Kebutuhan

Pengguna atau user merupakan orangorang yang terlibat dalam penggnaan aplikasi sistem penyewaan bus pada PO. Nuansa Ilham Sukabumi, untuk pengoprasiannya sistem yang dibuat nanti akan diperlukan beberapa orang yang terlibat diantaranya :

Administrator, yang tugasnya bisa menjalankan data master serta laporanlaporan.

Adapun kebutuhan sistem sebagai berikut :

A. Admin :

A1 : Admin dapat melakukan login

A.1.1 Admin dapat menginputkan username dan password

A2 : Admin memasuki menu master

A.2.1. Admin dapat mengisi data penyewa

A.2.2. Admin dapat mengisi data bus

A.2.3. Admin dapat mengisi data akun

A3 : Admin memasuki menu transaksi

A.3.1. Admin dapat mengisi penyewaan bus

A.3.2. Admin dapat menginput data transaksi jurnal

A4 : Admin memasuki menu laporan

A.4.1. Admin dapat mencetak laporan endapatan sewa
A.4.2. Admin dapat mencetak laporan pendapatan

A5 : Admin dapat melakukan logout.

b. Desain

Untuk memberikan gambaran yang jelas tentang sistem yang dibangun dibutuhkan rancangan sistem informasi, rancangan database, antar muka untuk memudahkan dalam proses implementasi sistem

Desain ERD (Entity Relationship Diagram)

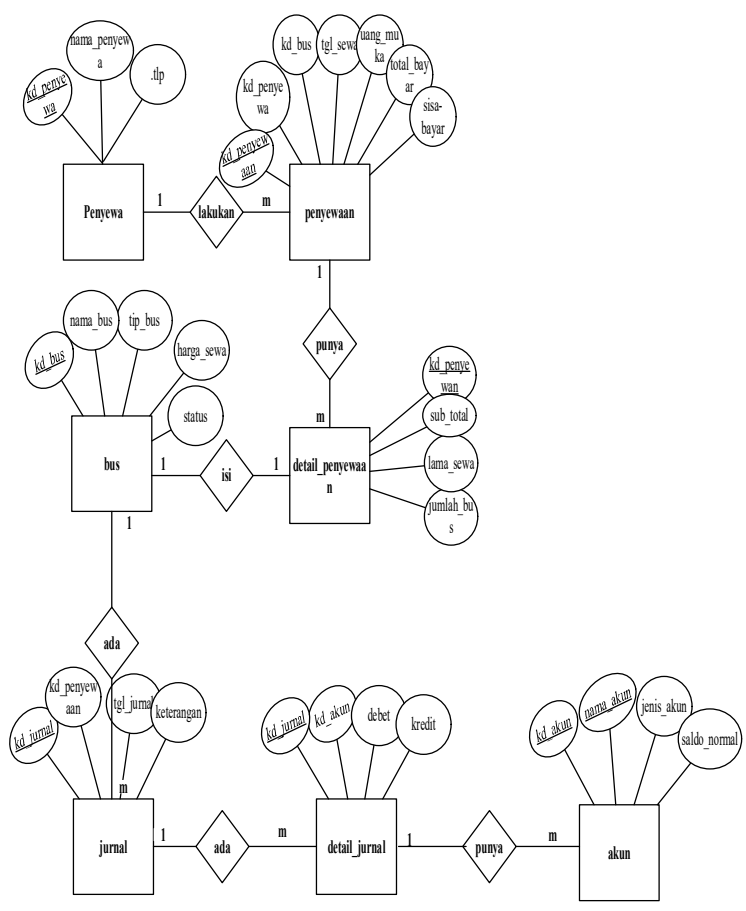

Gambar III. Sequence diagram

\section{c. Desain Sistem}

Desain sistem informasi penjualan obat disajikan dengan menggunakan usecase dan disesuaikan kebutuhan sistem.

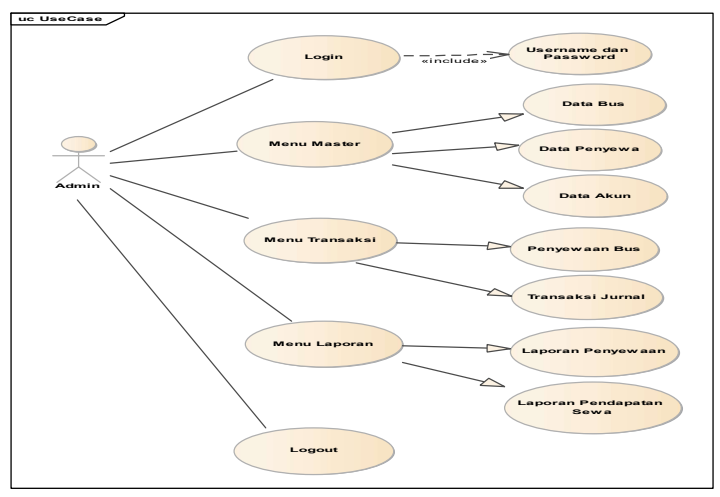

Gambar 1. Usecase Diagram Usulan Penyewaan Bus Pada PO.Nuansa Ilham 
Sumber : Olahan Peneliti (2019)

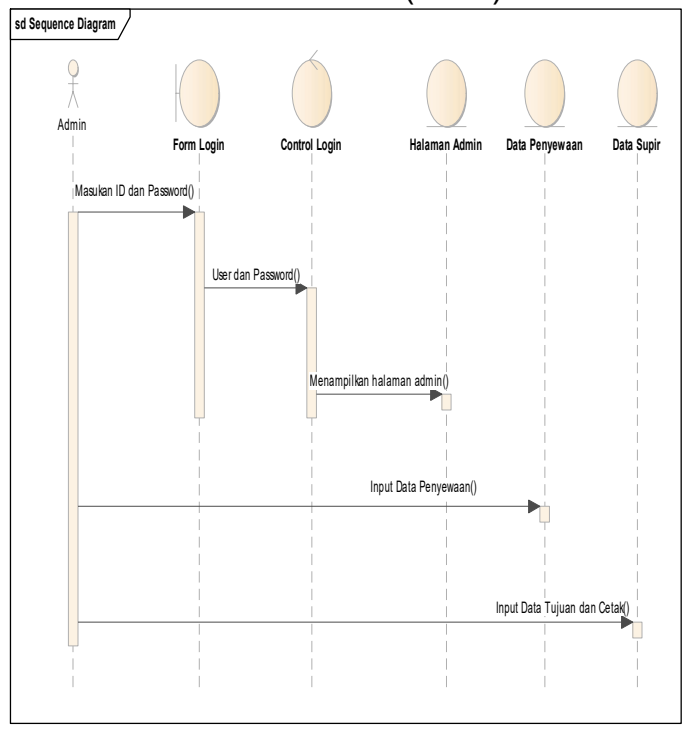

Gambar 4. Sequence Diagram Transaski Jurnal

Sumber : Sumber : Olahan Peneliti (2019) Gambar 2. ERD (Entity Relational Diagram)

Logical Record Structure (LRS)

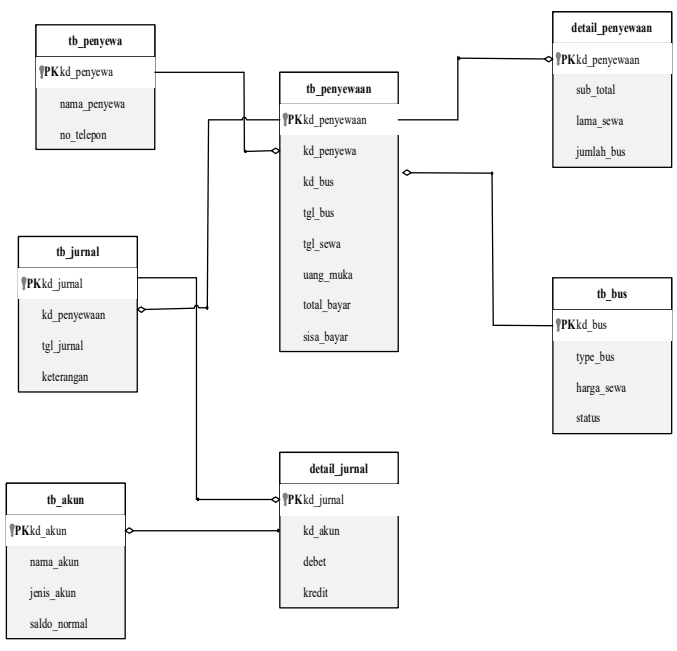

Deployment Diagram

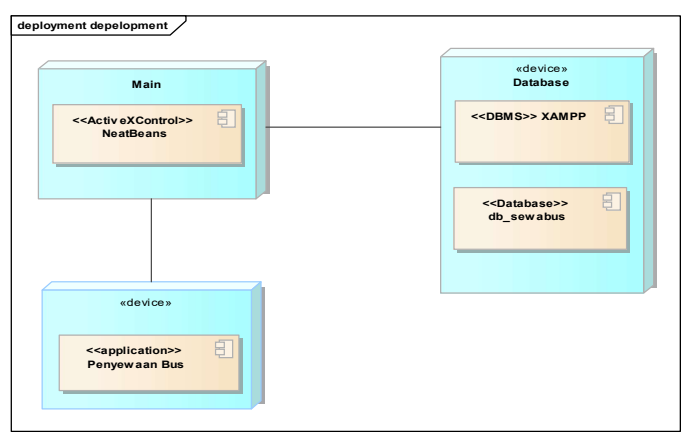

Gambar III.15. Deployment Diagram Penyewaan

\section{User Interface}

Halaman Login

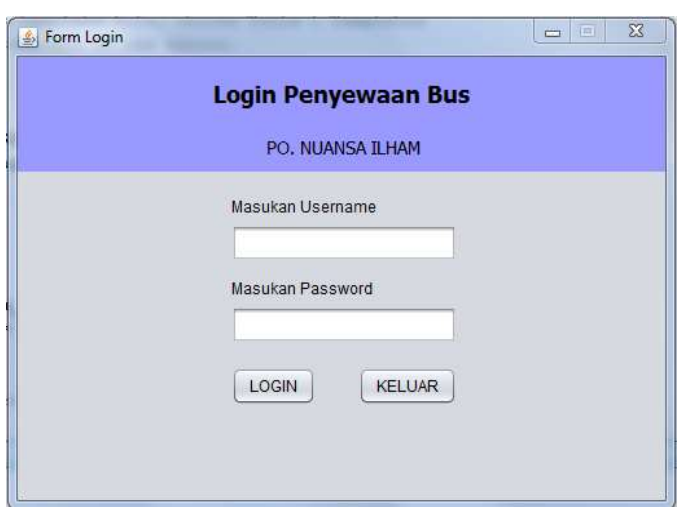

Gambar III.27. User Interface Halaman Login

\section{Form Penyewaan}

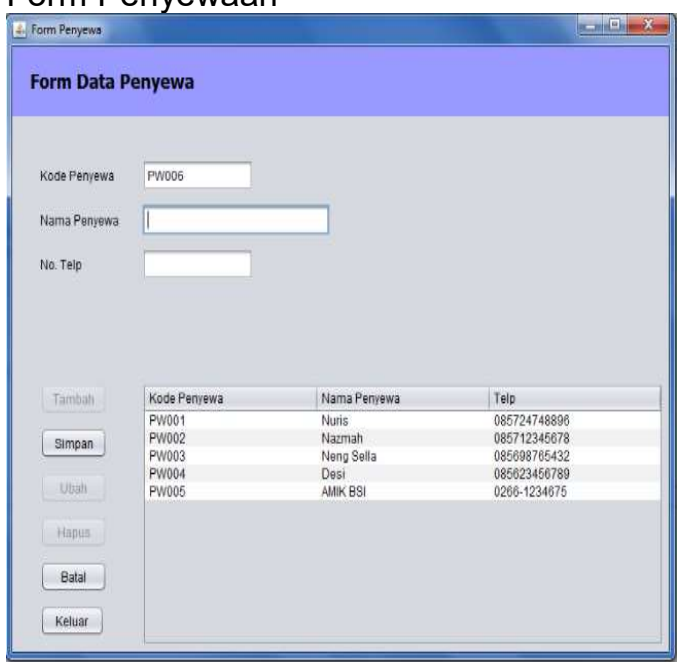

Gambar III.28. User Interface Penyewaan

Form Master Data Bus

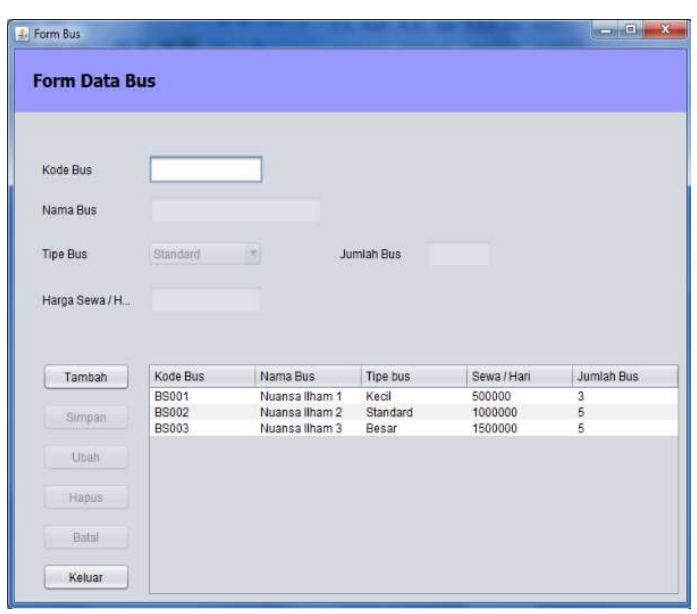

Gambar III.29. User Interface Data Bus 
Form Akun

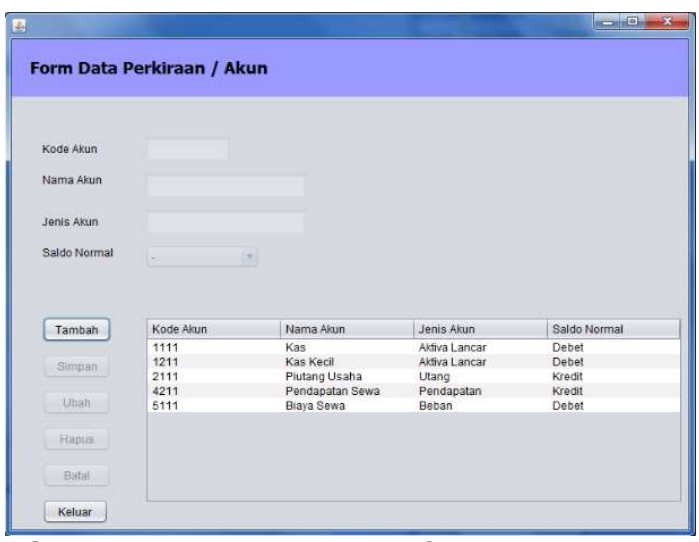

Gambar III.30. User Interface Data akun

Form Master Data Transaksi

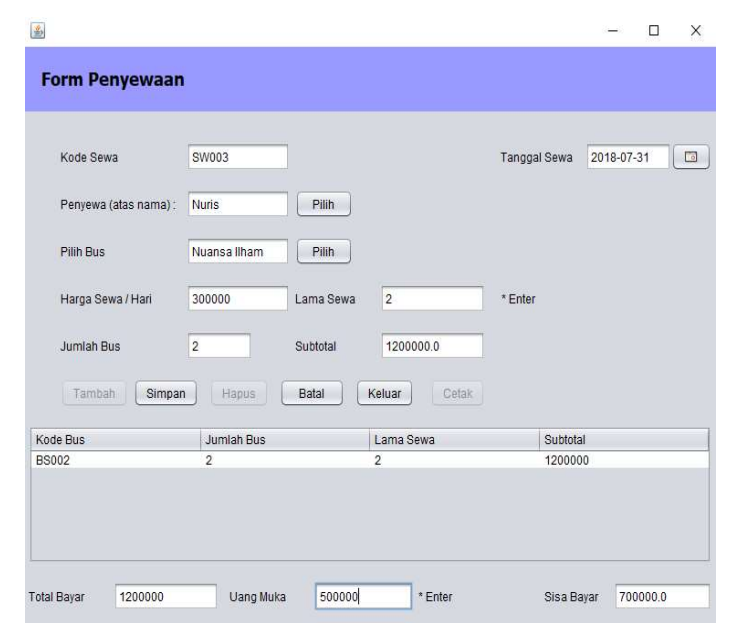

Gambar III.31. User Interface Data Transaksi

Form Master Data Transaksi Jurnal

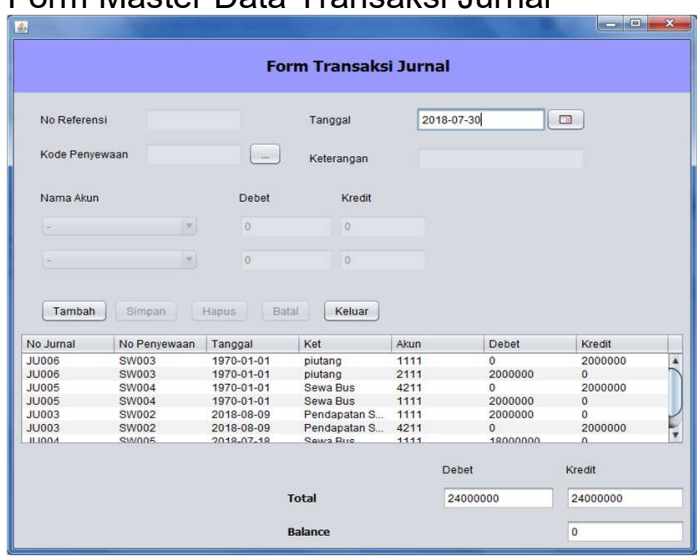

Gambar III.32. User Interface Data Transaksi Jurnal
Form Laporan

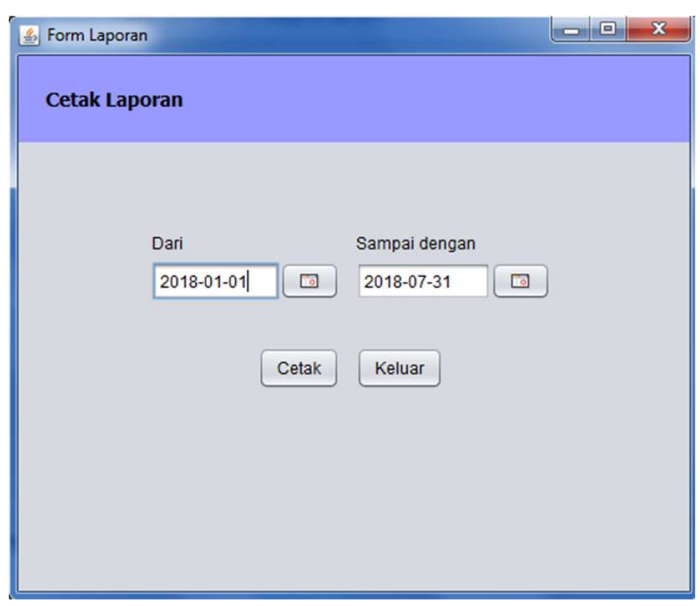

Gambar III.33. User Interface Laporan

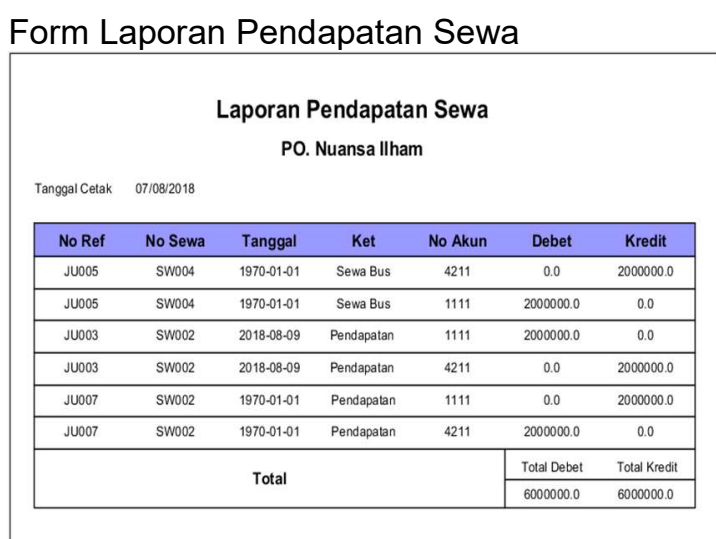

\section{Gambar III.34. User Interface Laporan Pendapatan Sewa}

\section{Pengkodean}

Komponen perangkat lunak adalah serangkaian unsur-unsur yang terdiri dari beberapa perangkat lunak program komputer yang digunakan untuk membantu proses kerja manusia (brainware). Berikut ini rancangan spesifikasi software usulan pada Klinik Altha Medika DBMS menggunakan My SQL Server dan bahasa Pemograman yaitu Java NetBeans IDE 8.1.

\section{Pengujian}

Untuk tahap pengujian atau testing, penulis menggunakan pengujian dengan metode blackbox, dimana pengujiannya dilakukan pada tampilan program apakah program dapat berjalan dengan baik sesuai yang diinginkan. 


\section{Simpulan}

Berdasarkan kajian serta tinjauan teori pendukung, maka dapat di tarik kesimpulan bahwa sistem berjalan penyewaan bus pada PO. Nuansa Ilham Prima Sukabumi masih manual, yaitu calon pelanggan harus datang sendiri ke kantor untuk melakukan pemesanan atau via telepon bagi yang sudah mengetahui cara pesan ke PO tersebut.

Dalam pengolahan data pemesanan masih manual karena sehingga tidak jarang terjadi kekeliruan dalam transaksi penyewaan, serta proses laporan keuangan hanya dibuat ketika diperlukan saja tidak secara berkala setiap bulan atau setiap periode akuntansi. Diharapkan dengan di buatnya sistem komputerisasi dapat mempermudah proses pencatatan transaksi penyewaan maupun proses laporan keuangan.

\section{Referensi}

Darmawan, D. (2013). sistem informasi manajemen. Bandung: PT .Remaja Rosdakarya Offest .

Daud, R., \& Windana, V. M. ( 2014). Pengembangan Sistem Informasi Akuntansi Penjualan Dan Penerimaan Kas Berbasis Komputer Pada Perusahaan Kecil . Jurnal Manajemen dan Bisnis Sriwijaya Vol.12 No.1 , 198-204.

Fatmawati. 2016. "Perancangan Sistem Informasi Pemesanan Katering Berbasis Web Pada Rumah Makan Tosuka Tangerang." JURNAL TEKNIK KOMPUTER AMIK BSI II (2): 33-41.

Fitria, \& Nisa, y. (2017). Sistem Informasi Penyewan Bus Online Berbasi Web. Jurnal Teknik Informatika Politeknik Hasnur Vol.03, 19-24.

Frayoga, D. M., \& Fitriani, L. (2016). Rancang Bangun Aplikasi Penyewaan Dan Pengelolaan Data Alat Kemping Berbasis Dekstop Pada Perusahaan Perorangan RZ Adventure. . Jurnal Algoritma Sekolah Tinggi Teknologi Garut, Vol 13,198204

Fridayanthie, E. W. \& mahdiati, T. (2016). Rancang Bangun Sistem Informasi permintaan Atk Berbasis Intranet.
Jurnal Khatulistiwa Informatika Vol.2, 126-138.

Hayuningtyas, Ratih Yulia. 2015. "Rancang Bangun Sistem Informasi Penjualan Tas Pada Toko Lokalop." Rancang Bangun Sistem Informasi Penjualan Tas Pada Toko Lokalop IV (2): 16067.

Hendini, Ade. 2016. "Pemodelan Uml Sistem Informasi Monitoring Penjualan Dan Stok Barang Barang (Studi Kasus: Distro Zhezha Pontianak)." Jurnal Khatulistiwa Informatika IV (2): 107-16.

Hutahaean, J. (2014). Konsep Sistem Informasi. Yogyakarta: Deepublish.

Mahatmyo, A. (2014). Sistem Informasi Akuntansi. Yogjakarta: CV.Budi Utama..

Ma'rifati, Imam Soleh. 2015. "Sistem Informasi Akuntansi Pendapatan Sumbangan Pembinaan Pendidikan (SPP) Pada SMU XYZ." Evolusi 3 (1): 1-8.

http://lppm3.bsi.ac.id/jurnal/index.php levo/article/viewFile/212/147.

Prasetyo, E. (2016). Rancang Bangun Aplikasi Persediaan Bahan Praktikum Pada SMK NEGERI 3 MODEL SEKAYU. Jurnal Teknik Informatika Poletiknik Sekayu (TIPS) 5,2.

Pratama, I. P. (2014). Sistem Informasi Implementasi. Bandung: Informatika Bandung.

Prasetyo, Agus wahyu. 2014. "Perancangan Sistem Informasi Rental Mobil Berbasis Website Pada Amien Rent Car Cepu," no. 1: 1-5.

Retno Wardhani, M. H. (2013). Game Dasardasar Hukum Islam dalam kitab Maba'diul Fiqih jilid 1. Jurnal Teknika Vol 5, 473-474.

Rita, \& Sharipuddin. (2016). Analisis Dan Perancangan Sistem Informasi Penerima Bantuan Pada Federasi Serikat Buruh Demokrasi Seluruh Indonesia (FSBDSI) Periode II Berbasis Web di Kabupaten Tebo . Jurnal Sistem informasi manajemen Vol.1 No.2, 117-109.

Setiawan, H. S. (2017). Program Aplikasi Perpustakaan Menggunakan JAVA NETBEANS. Jurnal Informatika Terpadu Vol.3, 1-6.

Sujarweni, V. W. (2015). V. Wiratna Sujarweni. Yogyakarta: Pustaka Baru Press . 
Wardhani, R. and Yaqin, M. H. (2013) 'Game Dasar- Dasar Hukum Islam Dalam Kitab Mabadi ' ul Fiqh Jilid l', Game Dasar-Dasar Hukum Islam Dalam Kitab Mabadi'ul Fiqh Jilid I, 5(2), pp. 473-478.

Zulfiandri,Sarip Hidayatuloh, M. A. (2014) 'Rancang bangun aplikasi poliklinik gigi (studi kasus: poliklinik gigi kejaksaan agung ri)', Depok: Universitas Gunadarma,

8(Kommit), pp. 473-482. Available at: http://portalgaruda.org. 